\title{
GENETICS OF LEAF RUST RESISTANCE IN ELEVEN CROSSES DERIVED FROM TWO LOW RESISTANT AND EIGHT HIGH RUST SEVERITY EGYPTIAN WHEAT CULTIVARS AT SEEDLING AND ADULT PLANT STAGES. Youssef, I. A. M. ${ }^{1}$; R. A. Ramadan ${ }^{2}$ and M. S. Hamada ${ }^{3}$ \\ 1- Wheat disease Res. Dept., Plant pathology Res. Institute, A.R.C. Giza, Egypt \\ 2- Wheat Res. Dept., Field Crop Res. Inst. ARC, Giza, Egypt \\ 3- Genetics Department, Faculty of Agriculture, Damietta University, Egypt
}

\begin{abstract}
Leaf rust caused by the biotrophic fungus Puccinia triticina, is one of the most important diseases of worldwide countries and Egypt. The use of resistance genes is of a great interest in numerous breeding programs. Our objectives were to determine the number of resistance gene pairs to wheat leaf rust present in eleven crosses derived from two low rust severity wheat cultivars i.e. Gemmeiza 9 and Sakha 94 with six and five high rust severity wheat cultivars, respectively, at both seedling in greenhouse and at adult plant stages under field conditions. The obtained results showed a high effective response against artificial and natural infection of wheat leaf rust at adult plant than these recorded at seedling stage. The study of combination between traditional wheat cultivars of Egyptian origin showing durable resistance proved to have a great value since they can provide new sources of resistance to such a disease.
\end{abstract}

\section{INTRODUCTION}

Wheat leaf rust (caused by Puccinia recondita Rob.ex Desm. f.sp. tritici Ericks. \& Henn.; Prt) is generally regarded as the most common and most widely distributed of the wheat rusts (Samborski 1985; Knott 1989). Although the damage caused by leaf rust is usually not severe, Samborski (1985) considered that (on a worldwide basis) the disease probably caused more damage in wheat than stem rust or stripe rust.

In Egypt, rust diseases are the most common and dangerous on wheat plants. Leaf rust, in particular, was the cause of eradicating many cultivars i.e. Giza 139, Mexpak 69, Super X and Chenap 70, because of their susceptibility. It had been widespread on most cultivars of wheat grown in Egypt. However, infection might be increased in the late sowings causing considerable losses in grain yield which reached $23 \%$ in some cultivars (Nazim et al., 1983). Moreover, some varieties were discarded very shortly after their release because of their susceptibility (Gomma, 1978). Although, fungicides have been used to control these diseases, resistance is the most economical and environmental friendly means of control. Leaf rust resistance in wheat cultivars is often conferred by one or more seedling genes. These genes have in many cases proven non-durable, being overcome by the development of matching virulence in the leaf rust pathogen, Puccinia triticinia. Although adult plant resistance genes (APR) are considered to be potentially more durable (Singh and Rajaram, 1992), the development of virulence has rendered some of them ineffective (Park and Mclntoch, 1994; 


\section{Youssef, I. A. M. et al.}

Huerta-Espino and Singh, 1996). Thus, despite the identification and deployment of a number of rust resistance genes to protect wheat crop, the emergence of virulent pathogen pathotype can restrict their durability and use. Consequently, there is a constant need to identify, characterize and deploy new source of resistance, whilst much effect has gene into genetic studies of seedling leaf rust resistance, many sources of APR remain uncharacterized. Previous studies have indicated that APR can be conferred by single genes (Mclntosh et al., 1995) or two or more genes (Singh et al., 2000). Various wheat breeding programs throughout the world have included mixed results in producing cultivars with long lasting, effective resistance to leaf rust. Spring wheat breeding program in North America (Kolmer et al., 1991), Mexico (Rajaram et al., 1988) and Australia (McIntosh, 1992) have generally been very successful in producing cultivars that have had high levels of durable and effective resistance. The objectives of the present work were to determine the number of gene pairs which are responsible for resistance to wheat leaf rust present in eleven crosses at seedling and adult plant stages.

\section{MATERIALS AND METHODS}

The present investigation was carried out at Tag-EL-Ezz Research Station, Temy-EL-Amdid Centr, Dakahliea Governorate and Wheat Disease Research Division, Plant Pathology Research Institute, Giza, Egypt, during 2010/2011 growing season. The main objective of this investigation is to assign the proper cross(es) from the perspective of leaf rust resistance, using Egyptian wheat cultivars have low infection type i.e. Gemmeiza 9 and Sakha 94, which were crossed to high infection type c.vs. i.e. Gemmeiza 1, Giza 163, Giza 164, Sakha 8, Sakha 69, Sids 1; Gemmeiza 7, Giza 164, Sakha 69, Sids 1 and Giza 168, respectively, with the exception of some crosses that were lost during cultural practices. The eleven crosses were tested at both greenhouse and field conditions at seedling and adult plant stages, in respect.

In 2008/2009 growing season, ten Egyptian wheat cultivars, previously mentioned were sown in $1.5 \mathrm{~m}$ long and $30 \mathrm{~cm}$ apart rows. Each row was sown by 15 seed with a distance of $10 \mathrm{~cm}$. The experimental unit included 4 rows of each parental cultivar. The parents were sown at different dates to obtain the pollen grains at the proper time. All possible crosses among (low $x$ high) and added to one cross (Low $x$ low) rust severity to produce the hybrid seed of eleven crosses.

In 2009/2010 growing season, part of eleven F1 crossess also were sown to produce F2 seeds and other part was kept for the final experiment in the next growing season.

In 2010/2011 growing season, greenhouse test : for the evaluation of parents, F1 and F2 plant populations against single race i.e. TKTT of leaf rust pathogen caused by $P$. triticina f.sp. tritici one pot was assigned for each parent or F1 seed as well as 13 pots for each of $F 2$ crosses were sown. Each pot contained 20 seeds, eight days old seedlings of them were uniformally inoculated with urediniospores of $(P$. triticina f.sp. triticl) using 
race TKTT of the pathogen. The inoculation of all tested materials under greenhouse conditions at seedling stage, was achieved using the gently rubbing technique described by Stakman et al., (1962). Infection type data against race TKTT were reported after fourteen days from inoculation according the method described by (Johnston, 1961) i.e. Immune $=0$, Nearly immune $=0 ;$, Resistant $=R$, Moderately resistant $=$ MR, Moderately susceptible $=$ MS, Susceptible $=$ S.

Infection types (IT) were recorded as either high (IT 3-4) or low (IT 0$2+$ ) as described by Long and Kolmer (1989) and Long et al., (2002).

\section{Field test:}

Under field conditions, eleven plots included 16 rows each, one row for each parent and $\mathrm{F} 1$ as well as thirteen rows for $\mathrm{F} 2$ plant populations were sown. The row was $2 \mathrm{~m}$ long, spaced $30 \mathrm{~cm}$ apart and seed were $10 \mathrm{~cm}$ apart within row. Each row was grown to 20 seed. The adjacent plots were separated by one meter wide belt. All plots were surrounded by a spreader area of one meter in width, planted with a mixture of the three highly susceptible cultivars to the leaf rust pathogen i.e. Morocco, Triticum Spelta Saharesis (T.S.S) and Sids 1. For field inoculation, the spreader plants were moistend and dusted with spore-powder mixture of the most prevalent leaf rust races in the area i.e. Race TKTT, Race PKTT and Race TTTT (one volume of fresh urediospores mixture : 20 volume of talcum powder). Dusting was carried out in the early evening at (sunset time) before dew formation and when air was still in. The inoculation of all plants was carried out at late tellering and early booting stage according to the method suggested by Tervet and Cassel (1951). Leaf rust severity was recorded at adult plant according to the modified cobb scale (Peterson et al., (1948). All regular cultural practices were applied during the growing season. Data were recorded according to the technical recommendations as rust severity for each plant. Plants were divided into classes according to the level of rust severity and intiation i.e. 0-10, 11-20, 21-30, 31-40 and 41-50, 51-60, 61-70, $71-80,81-90$. the first four classes were considered as entries having low rust severity, while other five classes were more than 40S were considered as entries having high rust severity Boulot (1997), Negm (2004) Shahin (2005), Khann et al., (2005) and Singh et al., (1998).

Statistical and genetic analysis :

Frequency distribution values were computed for parental, F1 and F2 plant populations for leaf rust infection type and leaf rust severity percentage under greenhouse and field conditions, respectively.

In respect to mode of inheritance, goodness of fit of the observed to the expected ratios of phenotypic classes leaf rust infection type and leaf rust severity were determined by the application of $X^{2}$ analysis according to Steal and Torrie (1960). Generally, the minimum number of effective genes controlling slow-rusting resistance (low rust severity) in each cross was estimated by the formula of Wright (1968). Degrees of dominance were calculated according to the method suggested by Romero and Frey (1973). Heritability in its broad-sense was estimated according to Lush (1949). 


\section{RESULTS}

The present investigation was carried out to study the genetics of leaf rust resistance in eleven crosses derived from ten Egyptian wheat cultivars having different levels of low or high rust severity. Data obtained were qualitatively and quantitatively analyzed as follows :

\section{A-Greenhouse tests :}

Genetic behaviour of ten Egyptian commercial wheat cultivars as affected by leaf rust race TKTT at seedling stage under greenhouse conditions : The infection type was studied within eleven crosses (resistant $x$ susceptible) i.e. Gemmeiza 9 with each of Gemmeiza 1, Giza 163, Giza 164, Sakha 8, Sakha 69, Sids 1, and Sakha 94 with Gemmeiza 7, Giza 164, Sakha 69, Sids 1, Giza 168. Data presented in Table (1) revealed the infection type of $\mathrm{F} 1$ plants tend to the side of high infection type similar to susceptible parent with nine crosses. But, the rest crosses i.e. Sakha $94 \times$ Giza164 and Sakha $94 \times$ Giza 168 tend to the direction of low infection type similar to their reaction of the resistant parent reaction.

Regarding the F2 plant populations data indicated that seven crosses out of eleven proved to have no segregation, the dominance tend to the side of susceptibility. On the other hand, the four other crosses segregated with numbers of plants with low and high infection type as clarified in Table (1) i.e. 18:195, 18:189, 97:119 and 121:97, respectively. These observed ratios fitted the theoretical expected ratio: i.e. 1:15, 1:15, 7:9 and 7:9 with probable values i.e. $0.250-0.100, \quad 0.250-0.100, \quad 0.750-0.500$ and $0.900-0.750$, respectively.

\section{B- Field test:}

Evaluation of parents, $\mathrm{F} 1$ and $\mathrm{F} 2$ plant populations against race mixtures of $P$. triticina f.sp. tritici at adult plant stage. Data presented in Table (2) showed that commercial cultivars Gemmeiza 9, Sakha 94 and Giza 168 displayed low rust severity (20S-40S), infection onset increesed in late growing season. However, Gemmeiza 1, Giza 163, Giza 164, Sakha 8, Sakha 69, Sids1, and Gemmeiza 7 showed high rust severity (40S-80S). The F1's tested plants demonstrated the same trend with one parent or two parents. Low rust severities were recorded with ten crosses, while, one cross showed high rust severity, i.e. Gemmeiza 9 x Sids 1 . 
Table (1): Infection type frequency distributions for parents, F1 and F2 plant populations. Phenotypic classes. Expected ratio, X2 and probable values of F2 populations of 11 (C.v. resistant $x$ C.v. susceptible) crosses as affected by inoculation with race TKTT of leaf rust ( $P$. triticina Eriks.) at seedling stage under greenhouse conditions in 2010/2011 growing season.

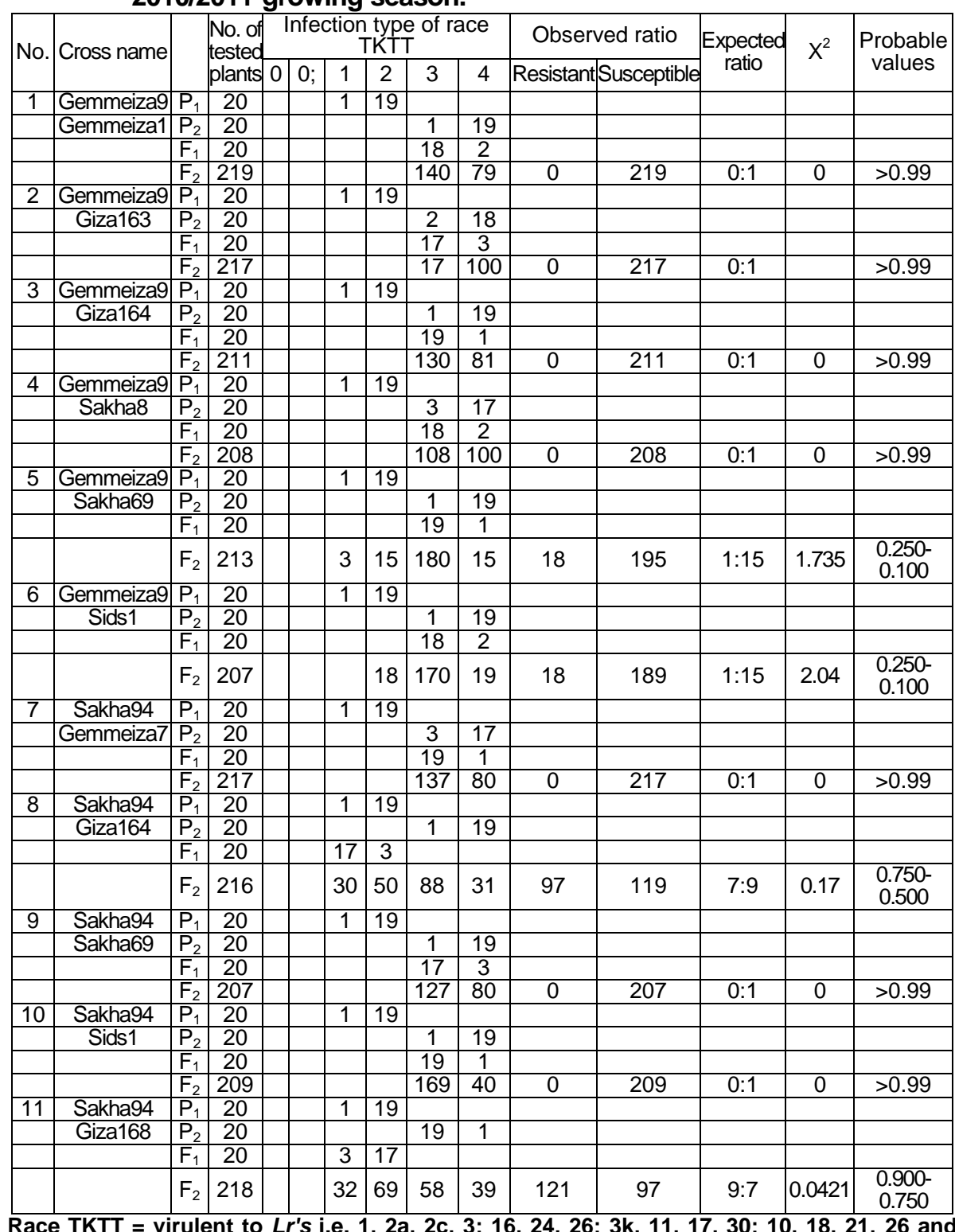
avirulent to $L r 9$ (Long and Kolmer 1989). 
Youssef, I. A. M. et al.

Table (2): Leaf rust severity (\%) frequency distributions of the two parents, F1 and F2 plant populations. Phenotypic classes, expected ratios, $\mathrm{X}^{2}$ and probable values of $\mathrm{F} 2$ population of $11(\mathrm{C} . \mathrm{V} \times$ C.V.) crosses as affected by inoculation with race mixtures leaf rust $(P$. triticina) at adult stage under field conditions in 2010/2011 growing season.

\begin{tabular}{|c|c|c|c|c|c|c|c|c|c|c|c|c|c|c|c|c|c|}
\hline \multirow[t]{2}{*}{ No. } & \multirow[t]{2}{*}{ Cross name } & & \multirow{2}{*}{$\begin{array}{l}\text { No. of } \\
\text { tested } \\
\text { plants }\end{array}$} & \multicolumn{8}{|c|}{ Disease severity classes \% } & \multicolumn{2}{|c|}{$\begin{array}{c}\text { Observed } \\
\text { ratio }\end{array}$} & \multicolumn{2}{|c|}{$\begin{array}{c}\text { Expected } \\
\text { ratio }\end{array}$} & \multirow[t]{2}{*}{$x^{2}$} & \multirow[t]{2}{*}{$\begin{array}{c}\text { Probable } \\
\text { values }\end{array}$} \\
\hline & & & & $0-10$ & $11-20$ & $21-30$ & $31-40$ & $41-50$ & $51-60$ & $61-70$ & $71-80$ & Low & High & Low & High & & \\
\hline$A$ & Low $\times$ High* & & & & & & & & & & & & & & & & \\
\hline \multirow[t]{4}{*}{1} & Gemmeiza9 & $\mathrm{P}_{1}$ & 20 & & 3 & 17 & & & & & & & & & & & \\
\hline & Gemmeiza1 & $\mathrm{P}_{2}$ & 20 & & & & & & & 18 & 2 & & & & & & \\
\hline & & $F_{1}$ & 20 & & & 18 & 2 & & & & & & & & & & \\
\hline & & $F_{2}$ & 217 & 19 & 40 & 88 & 26 & 22 & 13 & 9 & & 173 & 44 & 13 & 3 & 0.3292 & $\begin{array}{l}0.750- \\
0.500\end{array}$ \\
\hline \multirow[t]{4}{*}{2} & Gemmeiza9 & $\mathrm{P}_{1}$ & 20 & & 3 & 17 & & & & & & & & & & & \\
\hline & Giza163 & $P_{2}$ & 20 & & & & & & & 2 & 18 & & & & & & \\
\hline & & $\mathrm{F}_{1}$ & 20 & & & 18 & 2 & & & & & & & & & & \\
\hline & & $F_{2}$ & 208 & 10 & 15 & 52 & 43 & 42 & 21 & 15 & 10 & 120 & 88 & 9 & 7 & 0.174 & $\begin{array}{l}0.750- \\
0.500 \\
\end{array}$ \\
\hline \multirow[t]{4}{*}{3} & Gemmeiza9 & $\mathrm{P}_{1}$ & 20 & & 3 & 17 & & & & & & & & & & & \\
\hline & Giza164 & $\mathrm{P}_{2}$ & 20 & & & & & & 18 & 2 & & & & & & & \\
\hline & & $\mathrm{F}_{1}$ & 20 & & & 2 & 18 & & & & & & & & & & \\
\hline & & $F_{2}$ & 217 & 10 & 17 & 41 & 51 & 50 & 40 & 8 & & 119 & 98 & 9 & 7 & 0.179 & $\begin{array}{l}0.750- \\
0.500\end{array}$ \\
\hline \multirow[t]{4}{*}{4} & Gemmeiza9 & $\mathrm{P}_{1}$ & 20 & & 3 & 17 & & & & & & & & & & & \\
\hline & Sakha8 & $P_{2}$ & 20 & & & & & 17 & 3 & & & & & & & & \\
\hline & & $F_{1}$ & 20 & & 17 & 3 & & & & & & & & & & & \\
\hline & & $F_{2}$ & 219 & 40 & 88 & 56 & 18 & 12 & 13 & 2 & & 202 & 17 & 15 & 1 & 0.847 & $\begin{array}{l}0.500- \\
0.250\end{array}$ \\
\hline \multirow[t]{4}{*}{5} & Gemmeiza9 & $\mathrm{P}_{1}$ & 20 & & 3 & 17 & & & & & & & & & & & \\
\hline & Sakha69 & $\mathrm{P}_{2}$ & 20 & & & & & 18 & 2 & & & & & & & & \\
\hline & & $F_{1}$ & 20 & & 18 & 2 & & & & & & & & & & & \\
\hline & & $F_{2}$ & 209 & 21 & 97 & 53 & 22 & 13 & 3 & & & 193 & 16 & 15 & 1 & 0.6848 & $\begin{array}{l}0.500- \\
0.250\end{array}$ \\
\hline \multirow[t]{4}{*}{6} & Gemmeiza9 & $\mathrm{P}_{1}$ & 20 & & 3 & 17 & & & & & & & & & & & \\
\hline & Sids1 & $P_{2}$ & 20 & & & & & & & 2 & 18 & & & & & & \\
\hline & & $F_{1}$ & 20 & & & & & 19 & 1 & & & & & & & & \\
\hline & & $\mathrm{F}_{2}$ & 217 & & & 10 & 32 & 95 & 70 & 10 & & 42 & 175 & 3 & 13 & 0.059 & $\begin{array}{l}0.900- \\
0.750\end{array}$ \\
\hline \multirow[t]{4}{*}{7} & Sakha94 & $\mathrm{P}_{1}$ & 20 & & 3 & 17 & & & & & & & & & & & \\
\hline & Gemmeiza7 & $\mathrm{P}_{2}$ & 20 & & & & & & & 3 & 17 & & & & & & \\
\hline & & $F_{1}$ & 20 & & 18 & 2 & & & & & & & & & & & \\
\hline & & $F_{2}$ & 213 & 12 & 56 & 80 & 48 & 9 & 4 & 2 & 2 & 196 & 17 & 15 & 1 & 1.0979 & $\begin{array}{l}0.500- \\
0.250\end{array}$ \\
\hline \multirow[t]{4}{*}{8} & Sakha94 & $\mathrm{P}_{1}$ & 20 & & 3 & 17 & & & & & & & & & & & \\
\hline & Giza164 & $P_{2}$ & 20 & & & & & & 18 & 2 & & & & & & & \\
\hline & & $F_{1}$ & 20 & & 19 & 1 & & & & & & & & & & & \\
\hline & & $F_{2}$ & 206 & 8 & 51 & 65 & 37 & 26 & 11 & 8 & & 161 & 45 & 13 & 3 & 1.3057 & $\begin{array}{l}0.500- \\
0.250\end{array}$ \\
\hline 9 & Sakha94 & $\mathrm{P}_{1}$ & 20 & & 3 & 17 & & & & & & & & & & & \\
\hline & Sakha69 & $\mathrm{P}_{2}$ & 20 & & & & & \begin{tabular}{|l|}
18 \\
\end{tabular} & 2 & & & & & & & & \\
\hline & & $F_{1}$ & 20 & & 18 & 2 & & & & & & & & & & & \\
\hline & & $F_{2}$ & 219 & 42 & 85 & 59 & 16 & 11 & 6 & & & 207 & 17 & 15 & 1 & 0.8478 & $\begin{array}{l}0.500- \\
0.250\end{array}$ \\
\hline 10 & Sakha94 & $\mathrm{P}_{1}$ & 20 & & 3 & 17 & & & & & & & & & & & \\
\hline & Sids1 & $\mathrm{P}_{2}$ & 20 & & & & & & & 2 & 18 & & & & & & \\
\hline & & $\mathrm{F}_{1}$ & 20 & & 19 & 1 & & & & & & & & & & & \\
\hline & & $F_{2}$ & 217 & 37 & 97 & 40 & 26 & 15 & 5 & & & 200 & 17 & 15 & 1 & 0.906 & $\begin{array}{l}0.500- \\
0.250\end{array}$ \\
\hline $\mathrm{B}$ & Low $x$ Low & & & & & & & & & & & & & & & & \\
\hline 11 & Sakha94 & $\mathrm{P}_{1}$ & 20 & & 3 & 17 & & & & & & & & & & & \\
\hline & Giza168 & $P_{2}$ & 20 & & & 2 & 18 & & & & & & & & & & \\
\hline & & $\mathrm{F}_{1}$ & 20 & & 18 & 2 & & & & & & & & & & & \\
\hline & & $\mathrm{F}_{2}$ & 218 & 13 & 42 & 75 & 88 & & & & & 218 & 0 & 1 & 0 & 0 & $>0.99$ \\
\hline
\end{tabular}

*Low disease severity $x$ High disease severity

Meanwhile, the F2's plant population indicated that one cross out of eleven not segregated i.e. (Sakha $94 \times$ Giza 168) and indicating a dominance of partial leaf rust resistance. However, the rest of crosses showed 
segregation with numbers of plants with low and high rust severity Table (2) i.e. $173: 44,120: 88,119: 98,202: 17,193: 16,42: 175,196: 17,161: 45,202: 17$ and $200: 17$, these observed ratios fitted the theoretical expected ratios i.e. $13: 3,9: 7,9: 7,15: 1,15: 1,3: 13,15: 1,13: 3,15: 1$ and 15:1 with probable values i.e. $0.750-0.500,0.750-0.500,0.750-0.500,0.500-0.250,0.500-0.250$, $0.900-0.750, \quad 500-0.250, \quad 0.500-0.250, \quad 0.500 .0 .250$ and 0.500 .0 .250 , respectively.

Quantitative analysis:

To study quantitatively the genetic behaviour of wheat cultivars resistance to leaf rust, the two parents, F1 and F2 plant populations for each of the eleven crosses, were tested at seedling under greenhouse and adult plant under field conditions.

Under greenhouse conditions:

The average means for the two parents having low-infection type i.e. Gemmeiza 9 and Sakha 94 and the other eight cultivars that showed highinfection type i.e. Gemmeiza 1, Giza 163, Giza 164, Sakha 8, Sakha 69, Sids 1 , Gemmeiza 7 and Giza 168 were : 1.95, 1.95; 3.95, 3.9, 3.95, 3.85, 3.95, 3.95, 3.85 , and 3.05 , sequently Table (3). The F1 mean values in nine crosses were higher than their respective mid-parent values. But with two crosses i.e. Sakha 94 x Giza 164 and Sakha 94 x Giza 168 showed mean infection values lower than their respective mid-parent ones, indicating the presence of dominant resistance for low-infection type. The F2 means for these eleven crosses exhibited the same behaviour with the F1 means revealing the presence of resistance dominance with the two crosses previously mentioned in Table (3). Data obtained in Table (3) supported the high heritability values which were recorded with crosses exhibited means of infection type F1's and F2's lower than their respective mid-parents, were previously mentioned with two crosses in Table (3) But the low heritability values for the nine crosses Table (3) at seedling stage due to the effect of environmental conditions and growth stage were the highest effective for those crosses and the dominant alleles were not equally distributed for parents and vice versa in the case of high heritability.

Pathotype TKTT was avirulence / virulence on Lrg/- (Long and Kolmer 1989)

Under field conditions: the average means for the three low-rusting parents i.e. Gemmeiza 9, Sakha 94 and Giza 168 and the other tested seven cvs. i.e. Gemmeiza1, Giza 163, Giza 164, Sakha 8, Sakha69, Sids1 and Gemmeiza 7 were : $23.5,23.5,34.0 ; 66.0,74.0,56.0,46.5 ., 46.0,74.0$ and 73.0 sequently Table (4). The F1 mean values in the eleven crosses were $26.0 \%, 26.0 \%$, $34.0 \%, 16.5 \%, 16.0 \%, 45.5 \% 16.0 \%, 15.5 \%, 16.0,15.0 \%$ and $16.0 \%$, respectively. These means were lower than their respective mid-parent values indicating the presence of partial dominant resistance for low rusting severity. The F2 means for eleven crosses were: $28.0 \%, 37.79 \%, 37.25 \%$, $20.02 \%, 21.07 \%, 46.75 \%, 25.75 \%, 29.22 \%, 19.84 \%$, $19.79 \%$ and $25.91 \%$, in sequence. These means showed values lower than those calculated for their respective mid-parents demonstrating the presence of partial resistance dominance for low rust severity and confirming the obtained results from F1's Table (4). Expression of gene actions measured as the degree of dominance in $\mathrm{h} 1(\mathrm{~F} 1)$ and h2(F2) has been shown in Table (4). 
Table (3): Means of P1, P2, F1, F2, MP, degree of dominance of F1 and F2 as well as heritability and number of genes for leaf rust infection type of 11 (C.v $\times$ C.v.) crosses at seedling stage inoculated with pathotype TKTT $(P$. triticina) under greenhouse conditions in 2010/2011 growing season.

\begin{tabular}{|c|c|c|c|c|c|c|c|c|c|c|}
\hline \multirow{2}{*}{ No. } & \multirow{2}{*}{ Cross name } & \multicolumn{5}{|c|}{ Mean of infection type } & \multicolumn{2}{|c|}{$\begin{array}{ll}\text { Degree } & \text { of } \\
\text { dominance } & \end{array}$} & \multirow{2}{*}{ Heritability } & \multirow{2}{*}{$\begin{array}{l}\text { No. of } \\
\text { genes }\end{array}$} \\
\hline & & $\mathrm{P} 1$ & P2 & $\mathrm{F} 1$ & $\mathrm{~F} 2$ & MP & h1 & h2 & & \\
\hline & \begin{tabular}{|ccc}
\multicolumn{2}{|l}{ Low $x$ High } \\
P1 $\quad x \quad$ P2
\end{tabular} & & & & & & & & & \\
\hline 1 & Gemmeiza 9 x Gemmeiza 1 & 1.95 & 3.95 & 3.1 & 3.36 & 2.95 & 0.821 & 3.556 & 73.25 & 3.556 \\
\hline 2 & Gemmeiza 9 x Giza 163 & 1.95 & 3.9 & 3.15 & 3.46 & 2.925 & 0.2307 & 1.099 & 64.43 & 3.9314 \\
\hline 3 & Gemmeiza 9 x Giza 164 & 1.95 & 3.95 & 3.05 & 3.38 & 2.95 & 0.1 & 0.867 & 79.91 & 2.645 \\
\hline 4 & Gemmeiza 9 x Sakha 8 & 1.95 & 3.85 & 3.1 & 3.48 & 2.9 & 0.210 & 1.222 & 64.61 & 2.827 \\
\hline 5 & Gemmeiza 9 x Sakha 69 & 1.95 & 3.95 & 3.05 & 2.9718 & 2.95 & 0.1 & 0.0436 & 75.81 & 3.358 \\
\hline 6 & Gemmeiza 9 x Sids 1 & 1.95 & 3.95 & 3.1 & 3.005 & 2.95 & 0.15 & 0.11 & 65.49 & 5.636 \\
\hline 7 & Sakha94 x Gemmeiza 7 & 1.95 & 3.85 & 3.05 & 3.368 & 2.9 & 0.1578 & 0.985 & 68.127 & 2.4365 \\
\hline 8 & Sakha94 x Giza 164 & 1.95 & 3.95 & 1.15 & 2.406 & 2.95 & -1.8 & -1.088 & 94.06 & 0.449 \\
\hline 9 & Sakha 94 x Sakha69 & 1.95 & 3.95 & 3.15 & 3.386 & 2.95 & 0.2 & 0.87 & 68.706 & 4.566 \\
\hline 10 & Sakha 94 x Sids 1 & 1.95 & 3.95 & 3.05 & 3.19 & 2.95 & 0.1 & 0.48 & 69.295 & 4.664 \\
\hline 11 & Sakha 94 x Giza 168 & 1.95 & 3.05 & 1.85 & 2.302 & 2.5 & -1.181 & -0.72 & 94.578 & 0.1219 \\
\hline
\end{tabular}

C.v. = Egyptian commercial wheat variety

The negative values estimated in these crosses, also suggested the manifestation of partial dominance for leaf rust resistance and supported the F1 results. However, the heritability estimates in its broad-sense, calculated from the variance of parents, F1 and F2 for eleven crosses. The heritability values for all of the tested crosses are considered to be high. Meanwhile, these values were 95.27\%, 96.23\%, 95.26\%, 95.23\%, 91.42\%, 89.06\%, $91.96 \%, 95.60 \%, 92.72 \%, 93.48 \%$ and $87.59 \%$, respectively Table (4).

Table (4): Means of P1, P2, F1, F2, MP, degree of dominance of F1 and F2 as well as heritability and number of genes for leaf rust severity \% of 11 (C.v $x$ C.v.) crosses inoculated with race mixtures of $P$. triticina under field conditions in 2010/2011 growing season.

\begin{tabular}{|c|c|c|c|c|c|c|c|c|c|c|}
\hline \multirow[t]{3}{*}{ No. } & \multirow[t]{2}{*}{ Cross name } & \multicolumn{5}{|c|}{ Mean of rust severity } & \multicolumn{2}{|c|}{$\begin{array}{c}\text { Degree of } \\
\text { dominance }\end{array}$} & \multirow{2}{*}{ Heritability } & \multirow{2}{*}{$\begin{array}{l}\text { No. of } \\
\text { genes }\end{array}$} \\
\hline & & $\mathrm{P} 1$ & $\mathrm{P} 2$ & $\mathrm{~F} 1$ & F2 & MP & h1 & h2 & & \\
\hline & $\begin{array}{c}\text { Low xhigh } \\
\text { P1 } \times \text { P2 }\end{array}$ & & & & & & & & & \\
\hline 1 & Gemmeiza9 x Gemmeiza1 & 23.5 & 66.0 & 26.0 & 28.0 & 43.25 & -.0 .758 & -1.333 & 95.27 & 1.086 \\
\hline 2 & Gemmeiza 9 x Giza 163 & 23.5 & 74.0 & 26.0 & 37.74 & 48.75 & -0.900 & -0.872 & 96.23 & 1.212 \\
\hline 3 & Gemmeiza 9 x Giza 164 & 23.5 & 56.0 & 34.0 & 37.25 & 39.75 & 0.353 & -0.306 & 95.26 & 0.636 \\
\hline 4 & Gemmeiza 9 xSakha 8 & 23.5 & 46.5 & 16.5 & 20.022 & 35.0 & -1.608 & -2.604 & 95.239 & 0.497 \\
\hline 5 & Gemmeiza 9 x Sakha69 & 23.5 & 46.0 & 16.0 & 21.07 & 34.75 & -1.666 & -2.386 & 91.42 & 0.572 \\
\hline 6 & Gemmeiza 9 x Sids 1 & 23.5 & 74.0 & 45.5 & 46.75 & 48.75 & -0.128 & -0.158 & 89.06 & 4.191 \\
\hline 7 & Sakha 94 x Gemmeiza 7 & 23.5 & 73.5 & 16.0 & 25.75 & 48.5 & -1.3 & -1.82 & 91.96 & 2.330 \\
\hline 8 & Sakha 94 x Giza 164 & 23.5 & 56.0 & 15.5 & 29.22 & 39.75 & -1.492 & -1.295 & 95.607 & 0.672 \\
\hline 9 & Sakha 94 x Sakha 69 & 23.5 & 46.0 & 16.0 & 19.84 & 34.75 & -1.66 & -2.65 & 92.728 & 0.426 \\
\hline 10 & Sakha 94 x Sids 1 & 23.5 & 74.0 & 15.0 & 19.976 & 48.75 & -1.336 & -2.279 & 93.48 & 2.436 \\
\hline b- & Low $\times$ low & 23.5 & & & & & & & & \\
\hline 11 & Sakha 94 x Giza 168 & 23.5 & 34.0 & 16.0 & 25.91 & 28.75 & -2.428 & -1.079 & 87.59 & 0.1871 \\
\hline
\end{tabular}

C.v. = Egyptian commercial wheat variety 
Number of genes: Leaf rust severity means of parents and variance of $F 1$ and F2 were used to quantitative estimation of the number of genes, that condition partial leaf rust resistance in the tested wheat cultivars. The minimum number of effective genes controlling the partial resistance was digenic pairs for ten crosses. The estimated number was $1.08,1.21,0.63$, $0.49,0.57,4.91,2.33,0.67,0.42,2.43$ and 0.18 for all crosses, respectively \{Table (4)\}.

\section{DISCUSSION}

The seedling and adult plant stage rust studies gave evidance to expect the number of leaf rust resistance gene pairs and two unknown seedling and adult plant resistance (APR) genes that had an unequal effect on resistance, using a collection of Egyptian leaf rust races. Singh and Rajaram (1991) postulated that jupateco $73 S$ had Lr17a and complementary genes $L r 27+L r 31$ Singh and Mclntosh (1984). The leaf rust race TKTT used in seedling studies was virulent to all commercial wheat cultivars used except for the cultivars, i.e. Gemmeiza 9 and Sakha 94 that showed were avirulent (resistant). All commercial wheat cultivars showed susceptibility to race mixtures of $P$. triticina under both natural and artificial infection at adult plant stage under field conditions. The level of APR in wheat cultivars could be attributed to the combination of slow-rusting gene with other APR gene (s). The APR genes in commercial cultivars had dominant or strong partial dominant effects. Our results indicated that, when effective, one gene interacted with other APR gene and provided higher levels of APR than when those genes acted alone. When they were ineffective against corresponding virulent races, Lr23 failed to interact with Lr34 Zhang et al., (2008). Thus, there was no residual effect of gene Lr23. In Mexico, when tested against races virulent to Lr13 in the field, Lr13 did not enhance the resistance of Lr34 Singh (1992). Lr23 is a common gene in United States spring wheat cultivars Kolmer and Oelke (2006) and Oelke and Kolmer (2005). Spring wheat cultivars with combination of Lr16, Lr23 and Lr34 have displayed high levels of leaf rust resistance in United States Kolmer and Oelke (2006). In the present study, the resistance genes, in ten out of each of eleven crosses were ineffective against race TKTT used at seedling stage under greenhouse conditions. On the other hand, under field conditions, at adult plant stage, all crosses displayed partial resistance against race mixtures of $P$. triticina. The resistance conditioned by Lr34 was accorded with previous studies of 20$60 \%$ reduction in leaf rust severity Mclntosh (1992), Singh and Gupta (1992). The CIMMYT developed spring wheat "Brambling" has a high level of adult plant resistance (APR) to leaf rust. Brambling was crossed with spring wheat "Jupateca 73s" that was highly susceptible to current predominant $P$. triticina races. The F1 of Brambling / Jupateca 73s had much lower disease severity than mid-parent value. The two APR genes combined with Lr34 skewed the segregation of progeny toward Brambling phenotype. Similar levels of rust in the F1 because of partial dominance of slow-rusting genes were reported in genetic studies of lines carrying three to four slow-rusting genes Navabi et al., (2003) and Singh (1992). Generally, the frequency of homozygous parental type of resistance and homozygous parental type of susceptible lines in 


\section{Youssef, I. A. M. et al.}

segregating generations in those studies were proportional according to an additive gene model Zhang et al., (2008). Meanwhile, the lines with two slowrusting genes had approximately 5 to 30\% leaf rust severity Khanna et al., (2005) and Singh et al., (1998) and immune levels of resistance were reached by combining three or four genes Navabi et al., (2003), Singh, (1992 and 1994). The combination of the two slow-rusting genes other than Lr34 had immune levels of resistance in Mexico environments. Pyramiding slowrusting resistance genes can achieve stable high levels of resistance. The dominant nature of some of the slow-rusting resistance genes in Brambling cultivar are of great interest in breeding for durable rust resistance. This type of resistance will be easier to select for segregating generations as smaller population sizes would be required than when using lesser effects Zhang et al., (2008). Broers (1989) found that the correlation between growth stage (GS) and components of resistance were, however, low in the field as in the greenhouse. Also, Broers (1989) detected that the effect of growth stage (GS) on the epidemic is most pronounced on the flag leaf due to shorter average leaf age. The obtained results of eleven crosses of F2 plant populations were qualitativly and quantitativly analysed at seedling and adult plant stages. One cross, i.e. (Sakha $94 \times$ Giza 168) should have complimentary gene action and dominance of resistance at seedling stage , but no segregation at adult stage and displayed low-disease severity. Another cross i.e. (Gemmeiza $9 \times$ Sids 1 ). was segregated at seedling and adult stage to the side of the susceptibility. The rest of crosses at seedling stage seven crosses showed no segregation and two segregated to the tend of side dominance of susceptibility. On the other hand, at adult plant stage the rest of crosses were segregated with additive, inhibitory and complementary gene actions to the side of low rust severity. Denisson (1993) recorded low correlation between response in the greenhouse and in the field. He added, the actual level of acceptability of resistance is difficult to measure and varies with average levels of disease incidence, breeders will insure themselves with relatively high levels of resistance because leaf rust will be only one of many objectives in a breeding program. The mean concern then might be the avoidance of resistance based on hypersensitivity, especially if it is known to be controlled by a single gene Kolmer et al., (2010). Cultivars with specific genes for leaf rust resistance quickly select virulent leaf rust phenotypes. Certain combination of seedling resistance genes, may condition high levels of resistance in widely grown wheat cultivars for limited time. Given the large population size of $P$. tiriticina in the United States of effects of mutation, it would be expected that isolates with combination of virulence to the resistance genes would eventually appear. Soft red wheat cultivars such as Coldwell Kolmer (2009) and the accession Cl 13227, XU et al., (2005) have adult plant resistance to leaf rust that may prove to be more durable than the seedling resistance genes that have so frequently last effectiveness after a few years.

On the other hand, the quantitative analysis for leaf rust infection type at seedling stage and disease severity at adult stage of $F_{1}$ and $F_{2}$ plant populations in the eleven crosses (c.v. $x$ c.v.) were lower than that calculated for their respective mid- parents for all crosses at adult plant stage under field 
condition. While under greenhouse condition at seedling stage, only two crosses i.e. Sakha 94 x Giza 164 and Sakha 94 x Giza 168 exhibited mean of infection type of $F_{1}$ and $F_{2}$ plant populations lower than their mid- parents. The rest crosses appeared high values than their mid- parents, also showed low heritability values ( $64.43 \%-79.91 \%)$. The high heritability values were indicative for high rates of success in recovering the desired genes in future segregating generations.

Generally, low heritability values due to the effect of environmental conditions was the highest for that crosses and the dominant alleles which were not equally distributed for parents and the reverse was clarified in the case of high heritability values. These high values indicate that the selection for this trait in ealy segregating generations could be possible, but delaying it would be more effective. The obtained results are in harmony with those of Kuhan et al., (1980), Das et al., (1993), AbdEl-Latif et al., (1995) and Shehab El-Din et al., (1996) .

\section{REFERENCES}

AbdEI-Latif,A.H.; T.M. Shehab El-Din; M.M. El-Shami and S.A. Abo El-Naga (1995). Genetics of Triticum aestivum; Puccinia recondita tritici interaction in three Egyptian wheat cultivars . J. Agric. Res.Tanta Univ., $21: 182-188$.

Boulot, O.A. (1997). Further studies on leaf rust of wheat. Ph.D. Thesis plant pathology. Minufiya University. 290P.,

Broers, L.H.M. (1989). Partial resistance to wheat leaf rust in 18 spring wheat cultivars. Euphytica 44:247-258.

Das,M.K.; S. Rajaram; W.E. Kronstad; C.C. Mundt and R.P.Singh (1993). Associations and genetics of three components of slow rusting in leaf rust of wheat. Euphytica 68:99-109.

Denisson, C.J.M. (1993). Components of adult plant resistance to leaf rust in wheat. Euphytica 70:131-140.

Gomma, A.S.A. (1978). Report on the Egyptian wheat varieties and their development. Egyptian Soc. of Genetics Science , Cairo.

Huerta-Espino, J. and R.P. Singh (1996). Misconceptions on the durability of some adult plant resistance genes in wheat. Proc. $9^{\text {th }}$ European and Medit Cereal Rusts and Powdery Mildew Conf. Lunteren. The Netherlands. 109-111.

Johnston, C.O. (1961). Sixth revision of international register of physiologic races of the leaf rust of wheat (Puccinia recondita) report. Supplement, 92:19-30

Khanna, R.; U.K. Bansol, and R.G. Saini (2005). Genetics of durable resistance to leaf rust and stripe rust of an Indian wheat cultivar HD2009. J. Appl. Genet. 46:259-263.

Knott, D.R. (1989). The wheat rust-breeding for resistance. Berlin. SpringVerlag. $201 \mathrm{P}$.

Kolmer, J.A. (2009). Genetics of leaf rust resistance in the soft red winter wheat. "Coldwell". Crop Sci. 49:1187-1192. 
Kolmer, J.A. and L.M. Oelke (2006). Genetics of leaf rust resistance. Can. J. Plant Pathol. 28:1-9.

Kolmer, J.A.; D.L. Long and M.E. Hughes (2010). Physiologic specialization of Puccinia triticina on wheat in the United States in 2008. Plant Dis. 94:775-780.

Kolmer, J.A.; P.L. Dyck and A.P Roelfs (1991). An appraisal of stem and leaf rust resistance in North American hard red spring wheats and the probability of multiple mutations in populations of cereal rust fungi. Phytopath. 81:237-239.

Kuhan, R.C.; H.W. Ohm and G.E. Shaner (1980). Physiologic specialization of Puccinia triticina on wheat in the United States in 2008. Plant Dis. 94:775-780.

Long, D.L.; J.A. Kolmer; J. Leonard and M.E. Hughes (2002). Interaction of slow leaf rusting in suwon 85 wheat. Crop Sci. 230:655-659.

Long, D.L. and J.A. Kolmer (1989). A North American system of nomenclature for Puccinia recondita f. sp. tritici. Phytopath. 79: 525529.

Lush, J.L., (1949). Heritability of quantitative characters in farm animals. Hereditas, Supp. Vol. pp. 356-375. (Cited after Weber Agr. J. 44:202209).

Mclntosh, RA. (1992). Pre-emptive breeding to control wheat rusts. Euphytica 63:103-113.

McIntosh, RA.; C.R. Wellings and R.F. Park (1995). Wheat Rusts-An Atlas of Resistance Genes. CSIRO Publications, Canberra, Australia, 200pp.

Navabi, A.; R.P. Singh; J.R. Tewari and K.G. Briggs. (2003). Genetic analysis of adult-plant resistance of leaf rust in five spring wheat genotypes. Plant Dis. 87:1522-1529.

Nazim, M.; A.A. EL-Shehidi; Y.A. Abdou and Y.H. EL-Daoudi (1983). Yield losses caused by leaf rust on four wheat cultivars under epiphytotic levels. $4^{\text {th }}$ confer. Microbiol. Cairo, 1983, 17-27.

Negm. S.S.M. (2004). Partial resistance to leaf rust in some Egyptian wheat varieties. Ph.D Thesis. Faculty of Agric. Minu. Univ. pp.192.

Oelke, L.M., and J.A. Kolmer (2005). Genetics of leaf rust resistance in spring wheat cultivars Alsen and Norm. Phytopath. 95:773-778.

Park, R.F. and R.A. Mclntoch (1994). Adult plant resistance to Puccinia recondita f.sp. tritici in wheat. New Zealand Journal of Crop Horticultural Science, vol. 22:151-158.

Peterson, R.F.; A.B. Campbell and A.E. Hannah (1948). A diagrammatic scale for estimating rust intensity of leaves and stems of cereals. Can. J. Res. 26:496-500.

Rajaram, S.; R.P. Singh and S. Torres (1988). Current CIMMYT approaches inbreeding wheat for rust resistance. See Ref. 102a, pp.101-118.

Romero, G.E. and K.J. Frey (1973). Inheritance of semidwarfiness in several wheat crosses. Crop. Sci. 13:334-337.

Samborski, D.J. (1985). Wheat leaf rust. Pp.39-59 in: The cereal rusts. Volume II. Diseases, distribution, epidemiology, and control. Roelfs, A.P.; Bushnell, W.R. ed. Orlando, Academic Pres. 
Shahin, S.I.M. (2005). Resistance of Gemmeiza wheat cultivars to leaf rust disease. Ph.D. Thesis. Faculty of Agric. Minufiya Univ. pp.233.

ShehabEl-Din,T.M.;M.M.El-Shami and A.H. AbdEI-Latif (1996). Qualitative and quantitative genetic studies on Triticum aestivum; Puccinia recondita tritici interaction . J.Agric.Sci.,Mansoura Univ., 21(11):37693778.

Singh, R.P. (1992) Genetics of adult plant resistance of leaf rust in "Frontana" and three CIMMYT wheats. Genome 35:24-31.

Singh, R.P. (1994). Genetics of adult plant resistance to stripe rust in ten spring bread wheats. Euphytica. 72:1-7.

Singh, R.P. A. Mujeeb-Kazi and J.H. Espino (1998). Lr46:A gene conferring slow-rusting resistance to leaf rust in wheat. Phytopath. 88:890-894.

Singh, R.P. and A.R. Gupta (1992). Expression of wheat leaf rust resistance gene Lr34 in seedling and adult plant. Plant Dis. 76:489-491.

Singh, R.P. and R.A. McIntosh (1984). Complementary genes for reaction to Puccinia recondita f.sp. tritici in Triticum aestivum I. genetic and linkage studies . Can. J. Genet. Cytol. 26:723-735.

Singh, R.P. and S. Rjaram (1991). Resistance to Puccinia recondita f.sp. tritici in 50 Mexican bread wheat cultivars. Crop Sci. 31:1472-1479.

Singh, R.P. and S. Rjaram (1992). Genetics of adult-plant resistance to leaf rust in "Frontana" and three CIMMYT wheats Genome 35:24-31.

Singh, R.P.; J. Huerta-Espino and S. Rjaram (2000). Achieving nearimmunity to leaf and stripe rusts in wheat by combining slow- rusting resistance genes. Acta Phytopath. Entomol. Hung. 35:133-139.

Stakman, E.C.; D.M. Stewart and W.Q. Loegering (1962). Identification of physiologic races of Puccinia graminis var. tritici. Agricultural Research Service Publication E617. United States Department of Agriculture. $53 p$.

Steel, R.G.D. and T.H. Torrie (1960). Principles and procedures of statistics. MC. Graw Hill. N.Y; USA.

Tervet, I. and R.C. Cassel (1951). The use of cyclone separation in race identification of cereal rusts. Phytopath. 41:282-285.

Wright, S. (1968). Evolution and the genetics of populations vol. I. Genetic and biometric foundations. University of Chicago press. Chicago and London, 469pp.

Xu, X.; G. Gai; B. Carver; G.E. Shaner and R.M. Hwnger (2005). Molecular characterization of slow-leaf-rusting resistance in wheat. Crop Sci. 45:758-765.

Zhang, J.X.; R.P. Singh; J. Huerta-Espino; Y. Jin and J.A. Anderson (2008). Genetics of leaf rust resistance in Brambling wheat. Plant Dis. 92:1111-1118. 
Youssef, I. A. M. et al.

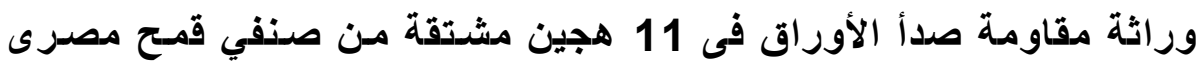

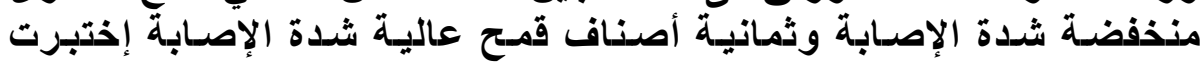

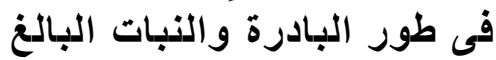


1- قسم بحوث أمراض القمح-معهر بحوث أمراض النباتات ـ مركز البحوث الزراعيةــ الجيزة ـ

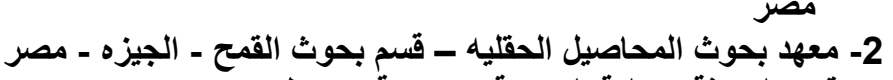

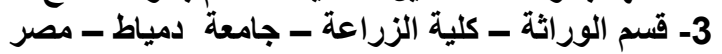

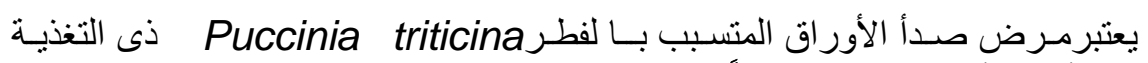

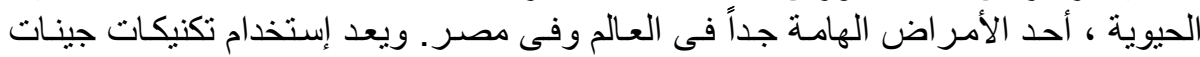

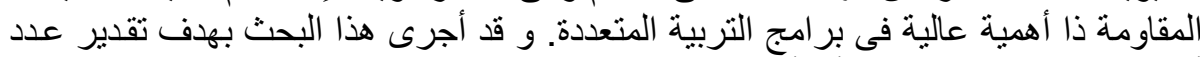



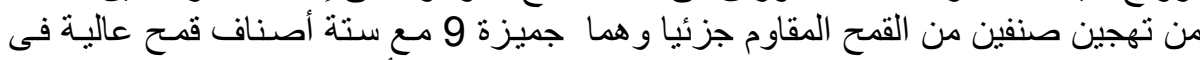



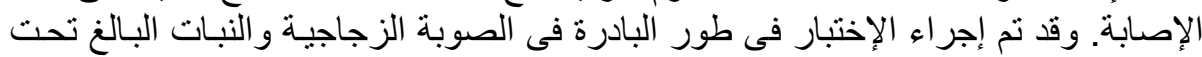







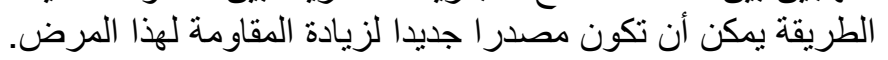

كلية الزراعة - جامعة المنصورة

مركز البحوث الزراعية

قام بتحكيم البحث

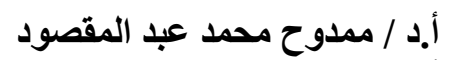
أ.د / صلاح الدين عبد الحميد ابو النجا 